\title{
Review: extended lactation in dairy cattle
}

\author{
J. Sehested ${ }^{1, \dagger} \odot$, C. Gaillard ${ }^{1, a}$, J. O. Lehmann², G. M. Maciel $^{3, b}$, M. Vestergaard ${ }^{1}$, \\ M. R. Weisbjerg', L. Mogensen², L. B. Larsen ${ }^{3}$, N. A. Poulsen ${ }^{3}$ and T. Kristensen²
} 'Department of Animal Science, Aarhus University, Blichers Allé 20, 8830 Tjele, Denmark; ${ }^{2}$ Department of Agroecology, Aarhus University, Blichers Allé 20, 8830 Tjele,
Denmark; ${ }^{3}$ Department of Food Science, Aarhus University, Blichers Allé 20, 8830 Tjele, Denmark

(Received 22 August 2018; Accepted 14 March 2019)

This paper reviews the effects of extended lactation (EXT) as a strategy in dairy cattle on milk production and persistency, reproduction, milk quality, lifetime performance of the cow and finally the economic effects on herd and farm levels as well as the impact on emission of greenhouse gas at product level. Primiparous cows are able to produce equal or more milk per feeding day during EXT compared with a standard 305-d lactation, whereas results for multiparous cows are inconsistent. Cows managed for EXT can achieve a higher lifetime production while delivering milk with unchanged or improved quality properties. Delaying insemination enhances mounting behaviour and allows insemination after the cow's energy balance has become positive. However, in most cases EXT has no effect or a non-significant positive effect on reproduction. The EXT strategy sets off a cascade of effects at herd and farm level. Thus, the EXT strategy leads to fewer calvings and thereby expected fewer diseases, fewer replacement heifers and fewer dry days per cow per year. The optimal lifetime scenario for milk production was modelled to be an EXT of 16 months for first parity cows followed by an EXT of 10 months for later lactations. Modelling studies of herd dynamics indicate a positive effect of EXT on lifetime efficiency (milk per dry matter intake), mainly originating from benefits of EXT on daily milk yield in primiparous cows and the reduced number of replacement heifers. Consequently, EXT also leads to reduced total meat production at herd level. For the farmer, EXT can give the same economic return as a traditional lactation period. At farm level, EXT can contribute to a reduction in the environmental impact of dairy production, mainly as a consequence of the reduced production of beef. $A$ wider dissemination of the EXT concept will be supported by methods to predict which cows may be most suitable for EXT, and clarification of how milking frequency and feeding strategy through the lactation can be organised to support milk yield and an appropriate body condition at the next calving.

Keywords: milk production, milk quality, reproduction, herd scenarios, lifetime scenarios

\section{Implications}

Improved breeding, feeding and management have led to intensive dairy systems with increased milk to meat production based on cows with improved lactation persistency and peak milk yield. The use of extended lactation can increase cows' lifetime and improve lifetime milk production and reduce the frequency per annual cow of the welfare issues associated with calving. Furthermore, extended lactation has the potential to improve the sustainability of dairy production by lower land use and emissions of greenhouse gas.

\footnotetext{
a Present address: PEGASE, INRA, AGROCAMPUS OUEST, 35590 Saint-Gilles, France.

b Present address: Innovation R\&D, Discover Department, Arla Foods Ingredients Group P/S, Sønderupvej 26, Videbaek 6920, Denmark.

† E-mail: jakob.sehested@anis.au.dk
}

\section{Introduction}

Lactation in dairy cows can be extended (EXT) beyond the standard 305-d lactation (STD) by delayed rebreeding leading to an extended calving interval (CI). Since the 1990s, various EXT strategies have been studied in a number of experiments (Bertilsson et al., 1997; van Amburgh et al., 1997; Österman and Bertilsson, 2003; Christiansen et al., 2005; Auldist et al., 2007; Kolver et al., 2007; Sorensen et al., 2008), and in one on-farm study (Arbel et al., 2001) where cows were deliberately managed to receive a delayed first insemination. Studies of an EXT strategy where cows likely went through an EXT not on purpose but because of reproductive failure were not included here.

An EXT strategy will decrease the number of calvings per year and decrease the number of health risk periods (mastitis, lameness, metabolic problems in early lactation) associated with calving (Ingvartsen et al., 2003), and thereby the EXT 
Sehested, Gaillard, Lehmann, Maciel, Vestergaard, Weisbjerg, Mogensen, Larsen, Poulsen and Kristensen

Table 1 ECM yield per day of Cl (lactating + dry days) of dairy cows in confinement systems during control and EXT. Number of observations (n)

\begin{tabular}{|c|c|c|c|c|c|c|c|c|}
\hline \multirow[b]{2}{*}{ Reference } & \multirow[b]{2}{*}{$n$} & \multirow[b]{2}{*}{ Parity } & \multicolumn{3}{|c|}{ Control lactation } & \multicolumn{3}{|c|}{ Extended lactation } \\
\hline & & & Lactating days & Dry days & $\mathrm{kg} \mathrm{ECM/day} \mathrm{of} \mathrm{Cl}$ & Lactating days & Dry days & $\mathrm{kg} \mathrm{ECM/day} \mathrm{of} \mathrm{Cl}$ \\
\hline \multirow{2}{*}{ Arbel et al. (2001) ${ }^{1}$} & 937 & Primi & 340 & 65 & 27.7 & 399 & 65 & 28.5 \\
\hline & & Multi & 320 & 69 & 32.8 & 369 & 67 & 33.0 \\
\hline \multirow[t]{2}{*}{ Christiansen et al. $(2005)^{2}$} & 86 & Primi & 319 & 43 & 20.3 & 465 & 46 & 20.4 \\
\hline & & Multi & 302 & 63 & 21.4 & 486 & 51 & 22.9 \\
\hline \multirow[t]{2}{*}{ Lehmann et al. $(2016)^{3}$} & 1379 & Primi & 325 & 46 & 22.0 & 431 & 50 & 23.2 \\
\hline & & Multi & 322 & 46 & 27.1 & 431 & 50 & 27.4 \\
\hline Rehn et al. $(2000)^{4}$ & 165 & All & 309 & 59 & 21.1 & 369 & 61 & 20.6 \\
\hline van Amburgh et al. (1997) & 4210 & Multi & 364 & 55 & 26.4 & 486 & 55 & 28.5 \\
\hline \multirow[t]{2}{*}{ Osterman and Bertilsson (2003) ${ }^{6}$} & 90 & Primi & 312 & 55 & 22.6 & 471 & 64 & 23.9 \\
\hline & & Multi & 293 & 85 & 23.8 & 419 & 116 & 22.8 \\
\hline
\end{tabular}

$\mathrm{ECM}=$ energy-corrected milk; Primi = Primiparous; Multi = Multiparous.

${ }^{1}$ High-yielders (Prim: $>30 \mathrm{~kg} \mathrm{ECM/day,} \mathrm{Mult:} \mathrm{305-d} \mathrm{yield} \mathrm{above} \mathrm{herd} \mathrm{average)} \mathrm{were} \mathrm{randomly} \mathrm{assigned} \mathrm{to} \mathrm{either} \mathrm{control} \mathrm{or} \mathrm{treatment.}$

2 Randomised 2 × 2-factorial design.

3 Observational study where farmers selected the majority of their cows for extended lactation.

${ }^{4}$ Random allocation at calving between control and experimental group. Swedish Holstein (SLB).

${ }^{5}$ Random allocation to one of four treatments within herd. Only second lactation cows. Cows were treated with bovine somatotropin from day 63 after parturition.

${ }^{6}$ Blocked by calving date and randomly allocated to one of four treatments.

strategy holds the potential to improve dairy cow longevity and lifetime efficiency. Farm economy should potentially benefit from this by reduced costs of insemination, reduced veterinary costs and reduced costs of rearing replacement heifers, which represent the second-largest annual expense of a dairy farm after the feed costs (Bach et al., 2008). Modern dairy cows have been selected for increased milk yield, but this is associated with a decrease in health and reproductive performance (Butler, 2000). With an EXT strategy, the cow is being inseminated in a stage of more positive energy balance (EB) and might also be dried off at a lower milk yield than when managed for STD. However, the individual lactation persistency is varying (Kolver et al., 2007). Both peak yield ( $\mathrm{kg}$ and days in milk (DIM)) and lactation persistency affect the ability of the individual cow to maintain a high daily milk production during EXT. Delaying rebreeding should itself improve lactation persistency as pregnancy exerts a negative effect on milk yield, especially during the last trimester (e.g. Brotherstone et al., 2004). However, milk yield and persistency might be affected by health incidences during lactation and can also be manipulated through management decisions, including milking frequency and feeding strategy (Stockdale, 2006; Kolver et al., 2007; Grainger et al., 2009).

Managing herds for EXT can be critical for milk quality if cows fail at sustaining high yields (Sorensen et al., 2008). Such scenario is of special relevance for seasonal calving systems, as EXT bulk milk can be problematic for the manufacturer of high-quality dairy products (Auldist et al., 2010).

Recently, focus has also been on the potential impact that an EXT strategy may have on greenhouse gas (GHG) emission from dairy production and herd profitability (Wall et al., 2012; Browne et al., 2015). However, the complex effects on herd dynamics and production performance of changing from an STD strategy to an EXT strategy make it less clear what the aggregated effect will be at herd and farm levels.
This paper aims at reviewing the effects of an EXT strategy in dairy cattle. The review will focus on effects of EXT on main sections: milk production and persistency, reproduction, milk quality, lifetime performance of the cow and herd and farm levels. The paper reviews the scientific literature including results from the recent Danish project REPROLAC on EXT strategy. The empirical basis of REPROLAC was (1) experiments at four private Danish farms (Lehmann et al., 2014, 2016 and 2017; Lehmann, 2016; Maciel et al., 2017); (2) experiment at the experimental farm, Aarhus University, Foulum (Gaillard, 2016; Gaillard et al., 2016a and 2016c; Maciel, 2016; Maciel et al., 2016); (3) lifetime modelling by use of the GARUNS model (Gaillard et al., 2016b); and (4) modelling of various herd scenarios using the SimHerd-model (Lehmann et al., 2016 and 2019).

\section{Milk production and persistency}

The ascending, peak and descending phases of milk yield during the lactation of a dairy cow characterise the course of milk production from calving through cessation by drying off. The rate of decline in milk yield after the peak phase broadly defines milk production persistency, and hence a combination of peak yield and lactation persistency defines total lactation milk production. The following subsections focus on how an EXT strategy and management decisions (milking frequency, feeding strategy) affect milk production and persistency.

Several studies (Table 1) compare EXT with STD. Some studies compare milk production per lactation day, whereas others compare milk production per feeding day, which is the sum of lactating and dry days. Extending the lactation dilutes the effect of including dry days on milk production per feeding day if dry period length is unchanged. 


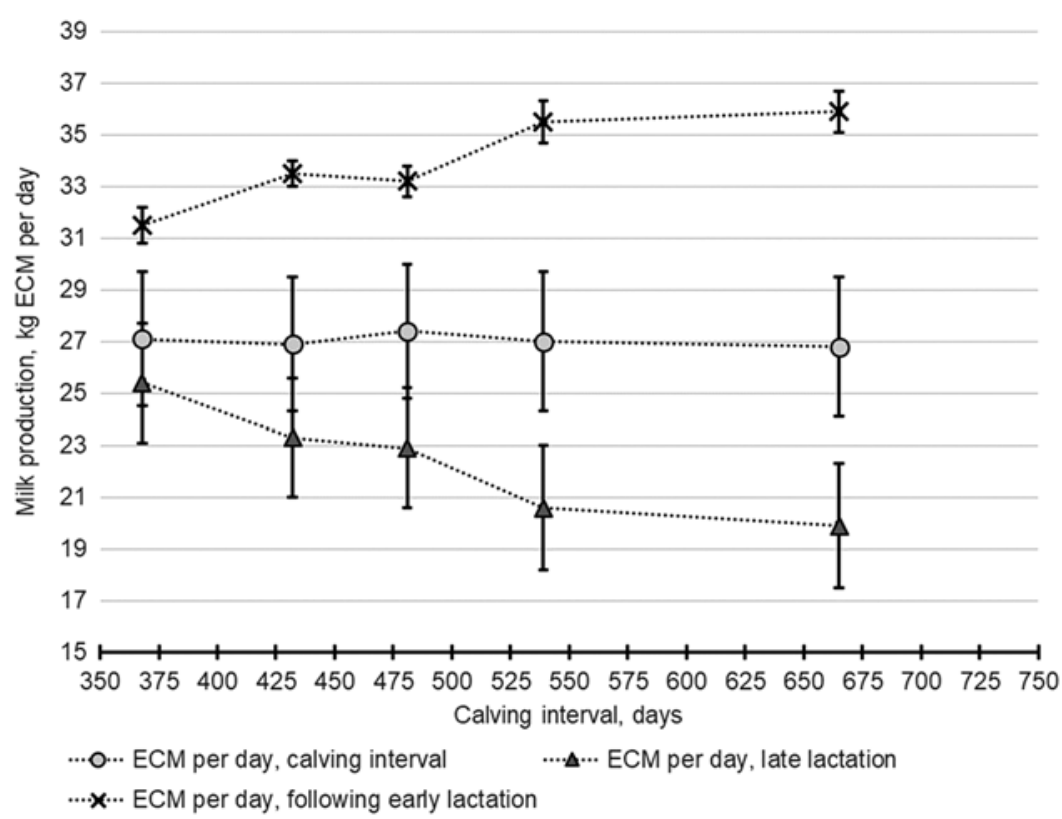

Figure 1 Mean ECM production per day in relation to five $\mathrm{Cl}$ groups. Values are per feeding day during $\mathrm{Cl}$ and per day during the last 45 days of lactation for multiparous cows as well as per day during the first 80 days of the second lactation following an extended first lactation. Error bars indicate standard error. Modified from Lehmann et al. (2016). ECM=energy-corrected milk; $\mathrm{Cl}=$ calving interval.

In confinement systems, primiparous cows are able to produce equal or more milk per feeding day during EXT compared with STD (van Amburg et al., 1997; Rehn et al., 2000; Arbel et al., 2001; Östermann and Bertilsson, 2003; Christiansen et al., 2005; Lehmann et al., 2016), whereas results for multiparous cows are inconsistent (Table 1). In pastoral, seasonbased systems, cows produced less milk per feeding day during EXT (Auldist et al., 2007; Grainger et al., 2009; Kolver et al., 2007), partly due to concomitant changes in grass/sward with season, although this could be compensated for with supplementary feeding (Grainger et al., 2009). Both Arbel et al. (2001) and Lehmann et al. (2016) based their analyses on cows selected for EXT, and that may skew their conclusions. However, they do demonstrate that a high milk yield during EXT is indeed achievable. Some studies (Bertilsson et al., 1997; Grainger et al., 2009; Kolver et al., 2007) note that not all experimental cows were capable of completing an EXT with a satisfactory level of milk production. Hence, selecting the most suitable cows for EXT is a potential optimisation strategy, and both production performance such as previous and current milk production (Lehmann et al., 2017) and physiological stage, described by Insulin-like Growth Factor 1 (IGF-1) and non-esterified fatty acid (NEFA) blood levels (Kay et al., 2007), may prove to be useful selection criteria.

Studies at the four private dairy herds in the REPROLAC project showed that (Figure 1) (1) both primi- and multiparous cows managed for longer lactations produced similar milk yields compared with cows managed for shorter lactations, albeit with a large individual variation, (2) early second lactation milk yield was increased for cows managed for a longer first lactation compared with cows managed for a shorter first lactation and (3) multiparous EXT cows had a lower yield during the last 45 days before dry-off than cows with a shorter lactation (Lehmann et al., 2016). These results illustrate that it in practice is possible to maintain a high milk yield with cows undergoing EXT while the large individual variation indicates that there is potential for developing selection methods to only manage high-persistent cows for EXT.

\section{Milking frequency}

Increasing milking frequency from two to three times per day generally increases daily milk production by $10 \%$ to $15 \%$ (Stockdale, 2006). Two studies confirm this response for EXT (Östermann and Bertilsson, 2003; Sorensen et al., 2008) and showed that increased milking frequency increased energycorrected milk (ECM) yield per feeding day by $13.2 \%$. Furthermore, the effect of milking three times per day on milk yield lasts beyond switching to milking two times per day if three times milking per day is initiated at calving, whereas there is no long-lasting effect if the cow is switched to three times milking per day later in lactation (Stockdale, 2006). However, it is unclear how far into an EXT that this effect would persist.

In the REPROLAC project, a milking robot was used at the experimental farm. Milking frequency was not fixed and could therefore vary between cows and over the lactation which might have had an effect on the production results. However, the results indicate that milking frequency was quite stable over the lactation with around 2.5 visits per day for the primiparous cows, while for the multiparous cows milking frequency decreased after the end of the mobilisation period from around 3.5 to 2.5 milkings per day.

\section{Feeding strategy}

There are few studies on feeding in relation to EXT reporting that feeding strategies may be able to increase lactation persistency. An individual feeding strategy based on live weight measurements was applied on the experimental farm in the 
Sehested, Gaillard, Lehmann, Maciel, Vestergaard, Weisbjerg, Mogensen, Larsen, Poulsen and Kristensen

Table 2 Selected references about EXT in dairy cows and its effects on pregnancy rates at $1^{\text {st }} \mathrm{Al}$

\begin{tabular}{|c|c|c|c|c|}
\hline Reference & Number of cows & Parity & Insemination time (STD v. EXT) & Pregnancy rates at $1^{\text {st }} \mathrm{Al}(\mathrm{STD} v$. EXT) \\
\hline \multirow[t]{2}{*}{ Arbel et al. (2001) } & 937 & Primi & 93 v. $154 \mathrm{~d}$ & $40.3 \%$ v. $43.5 \%$ NS \\
\hline & & Multi & 71 v. $124 \mathrm{~d}$ & $36.6 \%$ v. $38.7 \%$ NS \\
\hline Bertilsson et al. (1997) & 90 & All & 50 v. $90 \mathrm{~d}$ & $41.5 \%$ v. $50 \%$ \\
\hline Kolver et al. (2007) & 60 & Multi & 82 v. $451 \mathrm{~d}$ & $28.5 \%$ v. $53.5 \%$ \\
\hline Larsson and Berglund (2000) & 100 & All & 50 v. $140 \mathrm{~d}$ & $49 \%$ v. $56 \%$ \\
\hline Sawa and Bogucki (2009) & 11891 & All & $N A^{1}$ & Decrease \\
\hline \multirow[t]{2}{*}{ Schindler et al. (1991) } & 174 & Primi & $35-59$ v. $120-150 d$ & $66.6 \%$ v. $69.2 \%$ NS \\
\hline & & Multi & & $35.7 \%$ v. $64.4 \%$ * \\
\hline van Amburgh et al. (1997) & 108 & All & 60 v. $150 \mathrm{~d}$ & $35 \%$ v. $35 \%$ \\
\hline
\end{tabular}

EXT = extended lactation; $\mathrm{Al}=$ artificial insemination; NS = non-significant difference; Primi $=$ primiparous; Multi $=$ multiparous; EXT $=$ extended lactation STD = standard 305-d lactation.

${ }^{*}=$ significant difference $P<0.05$.

${ }^{1}$ A posteriori data analysis on 22432 lactations, a lactation was labelled as extended when its duration was above 305 days.

REPROLAC project (Gaillard et al., 2016a), where 62 cows were on an EXT strategy with a planned $\mathrm{Cl}$ of 18 months. Half of the cows received a diet enriched in energy (HD diet) in early lactation until individual live weight nadir from where they were shifted to a lower energy density diet (LD diet) until the end of the lactation. The other half of the cows were fed the LD diet throughout the lactation. During early lactation the multiparous cows fed the HD diet had a higher milk production compared with the cows fed the LD diet, but no diet effect on milk production was observed for primiparous cows. After the shift to the LD diet, the milk production (ECM) decreased faster for the HD-LD cows than for the LD-LD cows, meaning that the HD diet given in early lactation had a 300day negative carry-over effect on the lactation persistency for all the cows compared with cows fed the LD diet through EXT. This differs from the results of Bossen and Weisbjerg (2009), reporting that an individualised feeding strategy imposed in early lactation increased the lactation milk yield in early and mid-lactation, and also increased persistency of lactation in cows on a 12-month lactation cycle, without changing the feed efficiency and with reduced live weight (LW) losses. It can be due to diet differences between the two studies; indeed, in Bossen and Weisbjerg (2009) the difference between the high- and the low-energy diet was twice the difference used in the REPROLAC experiment, where the attained energy differences between HD and LD diets were relatively small.

Conclusion and perspectives on milk yield and persistency The achievable level of milk production during EXT and hence the ability to maintain a high level of persistency is essential for the success of the EXT strategy. Delaying rebreeding itself improves milk yield persistency. Management factors including milking frequency and feeding strategy in combination with different grouping of cows may also be useful to improve persistency. Less is known about cow characteristics and other factors that can predict cows' ability to both maintain a high level of milk production and a high level of persistency.

\section{Reproduction}

Dairy cows are genetically selected to produce more milk and consequently to partition nutrients towards the mammary gland (Veerkamp et al., 1995). The potential for milk production in first lactation is also influenced by the live weight and age at first calving (Markusfeld and Ezra, 1993). This increase in production is related to increased energy deficiency in early lactation which has negative effects on the reproductive performance of the cows (Butler, 2000). Therefore, delaying insemination until after peak yield, like with an EXT strategy, would potentially increase pregnancy rates (Schindler et al., 1991), decrease the number of inseminations needed per pregnancy and the frequency of anestrus treatment (Larsson and Berglund, 2000).

Pregnancy rate recordings for cows managed for EXT are rare and vary a lot. This variation might be due to large variations in individual reproductive performance, and to the quality of recordings that can vary from farm to farm (Pryce et al., 2004). Despite pregnancy rates seem to be improved with EXT (Table 2), in most cases no significant difference has been found between the pregnancy rates of cows managed for EXT and those of cows managed for STD.

Observational studies at the four private dairy herds in REPROLAC showed that inseminations per conception were below 2 across $\mathrm{Cl}$ groups (Lehmann et al., 2016), although the longest $\mathrm{Cls}$ did have the highest number of inseminations. Compared with the low-yielding cows, the high-yielding cows required more inseminations per conception (1.9 v. 1.4), had a lower conception rate at first insemination (50\% to $5 \% 4 v .67 .2 \%$ to $70.6 \%$ ) and took a higher number of days from first insemination to conception (63 to 73 days v. 48 to 54 days) (Lehmann et al., 2017). This may reflect that pregnancy difficulties increase with increasing milk yield. However, both studies were founded on cows selected for EXT, and those cows were likely the highest-yielding cows within herd. Thus, there may be a confounding between lactation length, milk yield and reproduction.

On the experimental farm in REPROLAC, more cows tended to express mounting behaviour at estrus \#8 than \#2 
(63.3\% v. 45.9\%, $P=0.06)$. However, in cows managed for EXT the reproductive parameters, defined as pregnancy rates (at first and second insemination), and number of inseminations were not improved compared with 10-month lactations (Gaillard et al., 2016b). Moreover, the level of live weight loss in early lactation, given as an estimation of $\mathrm{EB}$, had no effect on the reproductive parameters (Gaillard et al., 2016a).

\section{Conclusion and perspectives on reproduction}

Delaying insemination enhances mounting behaviour which could facilitate insemination at the right time. However, in most cases EXT has no effect or a non-significant positive effect on reproduction. Moreover, the level of negative EB in early lactation did not seem to explain the reproductive parameters. Factors like insemination protocol and timing, estrus detection, environment and genetics might have a higher impact on reproduction than feeding strategies or lactation length per se.

\section{Milk composition and quality}

There is a fundamental difference between STD late lactation milk and EXT milk. Late lactation milk is the milk collected in the last third of a given STD lactation before dry-off, whereas EXT milk refers to the milk collected from cows in which re-breeding has deliberately been postponed, and lactation persists beyond what is considered late lactation in a STD lactation. In this sense, comparisons between the composition of EXT and late lactation milk have been logical, although studies have suggested that impairment in STD late lactation milk quality takes place particularly in low-input systems, where cows experience a substantial yield decline (i.e. poor milking persistency) during late lactation (Auldist et al., 1996; Bertilsson et al., 1997; Sorensen et al., 2008).

Literature retrieved from the past 20 years documents a consensus that good-quality milk at EXT can be produced in both seasonal (Kolver et al., 2007; Grainger et al., 2009; Auldist et al., 2010) and continuous calving systems (Rehn et al., 2000; Österman and Bertilsson, 2003). The particularities of the genotypes, breeds, feeding and milking strategies investigated in these studies are summarised in Table 3. Milk fat, protein and total solids concentrations were reported to be, at least, the same at dry-off when comparing 15-, 18- or even 22-month $\mathrm{Cl}$ to 12-month Cl (Rehn et al., 2000; Österman and Bertilsson, 2003; Auldist et al., 2010). The same components have been documented to be higher in late- compared with mid-EXT milk from cows managed from 15- up to 22-month $\mathrm{Cl}$ irrespective of calving system, which was confirmed in two publications related to REPROLAC (Maciel et al., 2016 and 2017).

When it comes to the detailed composition and quality of EXT milk in relation to dairy processing, published data are scarce. The study from Auldist et al. (2010) reported that the higher protein and fat concentrations and an unaffected $\mathrm{CN}$ (casein) to protein ratio and protein composition of the milk produced by cows in the second half of 22-month lactation compared with milk produced by cows in 10-month lactation resulted in superior cheese-making properties and cheese quality. Accordingly, Sorensen et al. (2008) suggested positive attributes of EXT milk for cows milked trice daily; cows that did not receive concentrate supplement and were only milked twice daily showed a poor persistency, and a progressively reduced $\mathrm{CN}$ to protein ratio during the EXT period. Our recent publications from REPROLAC confirm that the improved cheese-making properties of EXT milk are linked to the increased concentrations of proteins and casein (Maciel et al., 2016 and 2017). Those increases were not affected by the distance from calving to conception, but were instead related to the gestational stage in cows managed for 15- or 18-month $\mathrm{Cl}$. Regardless of $\mathrm{Cl}$, milk composition was enhanced from 180 to 90 days before calving, as the chymosininduced gels were firmer and tended to be built up at a faster rate, although rennet coagulation time (RCT) did not differ between the referred periods. In a similar way, relative concentration of major milk proteins also changed towards the end of the lactation with an increase in total $\kappa-\mathrm{CN}$; gly cosylated $\kappa-\mathrm{CN}$ and $\alpha$-LA concentrations, and decrease in $\alpha_{S_{1}-}-\mathrm{CN}$ and $\beta$-LG (Maciel et al., 2017). Besides that, our recent findings have also revealed that the udder integrity indicators; SCC, pH, conductivity or free amino terminals (i.e. natural proteolysis in milk) were not significantly different from mid-lactation towards the end of the EXT. On the other hand, a higher chloride level was observed in late EXT, but seemed to be associated with the reduction in milk yield and concentration of milk solids, due to its strong negative correlation with lactose (Maciel et al., 2016). Bertilsson et al. (1997) reported salty taste of EXT milk from lowyielding cows, which may relate to chloride concentrations. However, late-EXT milk of healthy cows that was evaluated by a trained sensory panel did not present any sensory disadvantage in relation to mid-EXT milk, as both pasteurised full-fat and skim milk produced by healthy cows at lateEXT was graded similarly (Maciel et al., 2017), or better (Maciel et al., 2016) than mid-EXT milk for sensory attributes.

\section{Conclusion and perspectives on milk quality characteristics} The outlined studies document that good-quality milk can be produced with EXT in both seasonal and continuous calving systems, and even in low-input organic farm systems. No major concern in relation to overall milk quality and technological properties of milk from EXT compared to STD have been reported. However, quantification of minor milk components, such as specific proteins, fatty acids and metabolites, could potentially uncover some changes in underlying metabolic pathways behind the secretory mammary epithelium dynamics, for example, in relation to cell turnover and cellular activity (Garnsworthy et al., 2006; Murney et al., 2015) during EXT, which has not been explored in the reported studies. It is important to also measure the bulk concentration of minor components (i.e. protein fractions and minor whey proteins, salts, enzymes and metabolites), specifically for seasonal calving systems, as the share of whey-based ingredient sales on the income of whey-processing dairies is increasing together with its gradually higher value in the market (Lagrange et al., 2015). 
Sehested, Gaillard, Lehmann, Maciel, Vestergaard, Weisbjerg, Mogensen, Larsen, Poulsen and Kristensen

Table 3 Summary of aspects associated with good-quality milk in dairy cows at EXT retrieved from literature

\begin{tabular}{|c|c|c|}
\hline Aspects & Findings & Remarks \\
\hline Genotype and breeds & $\begin{array}{l}\text { - Swedish Holstein and Swedish Red and White cows } \\
\text { had similar protein and slightly higher fat } \\
\text { concentration at the end of 15-month CI [1] } \\
\text { - Both Holstein-Friesian of North American and } \\
\text { New Zealand origin produced milk with high-protein } \\
\text { concentration from mid- to late-EXT [3] } \\
\text { - Cross-breed cows with high percentage of Jersey in } \\
\text { the pedigree produced milk with higher protein, } \\
\text { fat and CN to protein ratio from mid- to late-EXT [8] }\end{array}$ & $\begin{array}{l}\text { - Changes in milk composition due to stage of } \\
\text { lactation overcome that of genotype or breed effect; } \\
\text { the magnitude of changes, however, may be } \\
\text { breed/genotype related } \\
\text { - The capacity to persist at EXT and information on } \\
\text { the composition of milk from breeds/cross-breeds } \\
\text { other than Holstein-Friesian are scarce }\end{array}$ \\
\hline Feeding strategy & $\begin{array}{l}\text { - Increasing the offer of concentrate DM/cow per day } \\
\text { from } 0 \text { to } 6 \mathrm{~kg} \text {, from calving to dry-off, promoted an } \\
\text { increase in milk fat concentration [3] } \\
\text { - SCC was lower and fat, lactose, protein and CN to } \\
\text { protein ratio were higher in EXT milk when cows } \\
\text { were offered } 3 \mathrm{~kg} / \text { day of concentrate [4] } \\
\text { - Cows on pasture receiving high-energy or TMR diets } \\
\text { produced milk with higher concentrations of protein } \\
\text { at EXT, but fat was lower for the TMR fed group [5] } \\
\text { - Supplying cows high-energy diet in the mobilisation } \\
\text { period did not exert a carry-over effect on EXT milk } \\
\text { quality and composition }[6,7]\end{array}$ & $\begin{array}{l}\text { - There is not enough evidence that energy intake } \\
\text { causes significant changes in milk composition } \\
\text { compared to lactation stage itself } \\
\text { - By adopting feeding strategies that support } \\
\text { persistency of healthy cows, milk quality will } \\
\text { most likely not be impaired }\end{array}$ \\
\hline Milking strategy & $\begin{array}{l}\text { - Increasing milking frequency from two to three times } \\
\text { in cows managed for 18-month } \mathrm{Cl} \text { lowered the } \\
\text { concentrations of fat and protein at EXT, although } \\
\text { milk yield was increased [2] } \\
\text { - Cows managed for 18-month } \mathrm{Cl} \text { when milked three } \\
\text { instead of two times/day kept constant CN to protein } \\
\text { ratio and lower SCC at EXT[4] }\end{array}$ & $\begin{array}{l}\text { - Different milking strategies to support persistency } \\
\text { in primi- or multiparous cows and its impact on } \\
\text { detailed milk composition are still to be verified } \\
\text { - The physiological mechanisms related to the } \\
\text { mammary epithelium dynamics and its impact on } \\
\text { detailed milk composition (including protein profile) } \\
\text { are not fully understood }\end{array}$ \\
\hline
\end{tabular}

$\mathrm{Cl}=$ calving interval; $\mathrm{EXT}=$ extended lactation; $\mathrm{SCC}=$ somatic cell count; $\mathrm{TMR}=$ total mixed ration; $\mathrm{CN}=$ casein.

[1] Rehn et al. (2000); [2] Österman and Bertilsson (2003); [3] Kolver et al. (2007); [4] Sorensen et al. (2008); [5] Grainger et al. (2009); [6] Auldist et al. (2010); $[7,8]$ Maciel et al. $(2016,2017)$.

\section{Lifetime scenarios for cows}

In REPROLAC we studied the effect of an EXT strategy with 18-month $\mathrm{Cl}$, corresponding to a 16-month lactation period, on productive and reproductive performances on a time scale of one lactation per cow at the experimental farm. Then, a modelling approach allowed us to go further by predicting the lifetime effect of using an EXT strategy on cows' performance testing different length of EXT $(12,14,16$ or 18 months). We used the GARUNS model developed by Martin and Sauvant (2010), a dynamic and stochastic model taking into account the changing priorities in nutrient partitioning of an animal as its ages, through repeated reproduction cycles in combination with a reproduction sub-model (Phuong et al., 2015). The lifetime scenario optimising the productive performance of high-yielding Holstein cows would be to have an EXT of 16 months at first parity, followed by 10-month lactations (EXT-STD scenario). The scenario where all cows were managed for 16-month lactation gave a performance similar to the EXT-STD scenario (Gaillard et al., 2016b). It should be noted that lifetime predicted in the model scenarios is only defined by reproductive performance and culling rules, as the effects of diseases are not yet incorporated in the model (Phuong et al., 2015).

Primiparous cows have a lower peak yield than multiparous cows, but their persistency is higher (Bar-Anan and Genezi, 1981) so they maintain a long lactation with a decent daily milk yield in late lactation (Ratnayake et al., 1998). Gaillard et al. (2016c) also reported differences in weight loss and metabolite and hormone concentrations between primiparous and multiparous cows, indicating that primiparous cows promote nutrient partitioning into body growth and not only into milk (Wathes et al., 2007). This might explain why extending the duration of lactation of primiparous cows seems more advantageous for the following lactations than for multiparous cows. This modelling approach is the first to report results on lifetime scale of the cows. Experimental studies or at least on-farm data are needed at this scale to confirm the results obtained. However, other studies at the scale of one lactation showed that EXT was more advantageous for primiparous cows than for multiparous cows in terms of daily milk yield and economical profitability (Arbel et al., 2001; Osterman and Bertilsson, 2003) (Figure 2). 


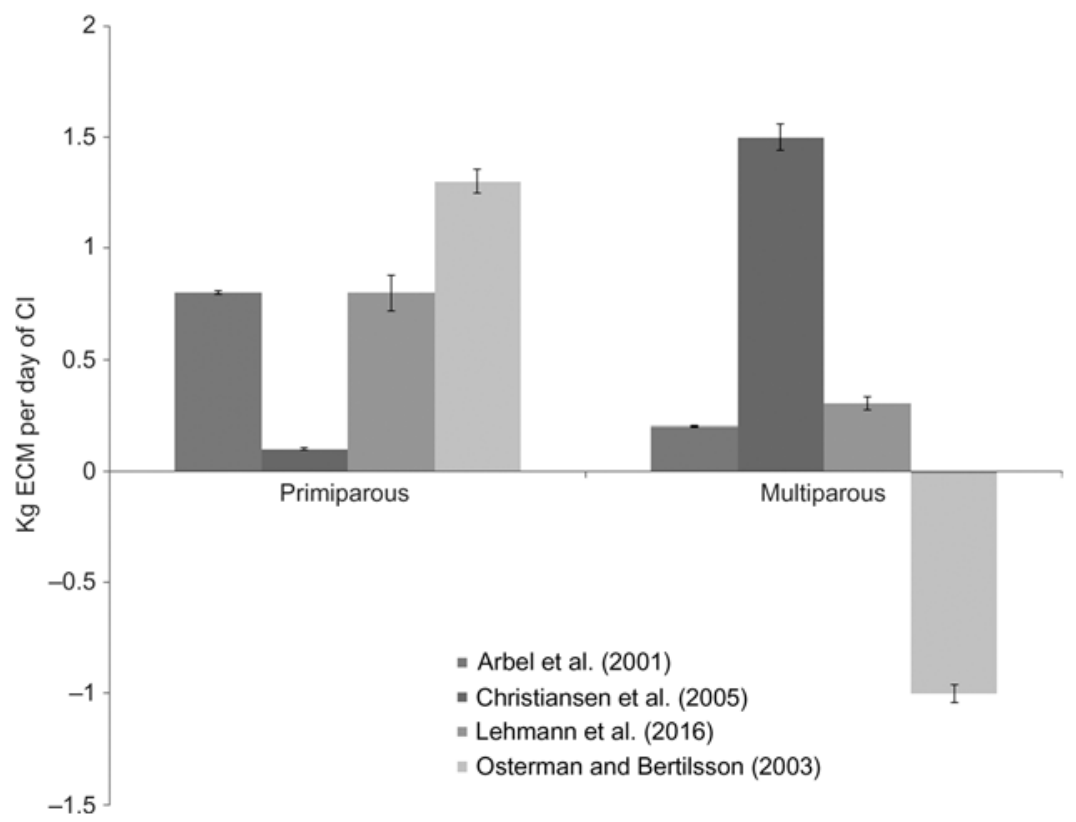

Figure 2 Difference in kilogram ECM per day of $\mathrm{Cl}$ between control and EXT in primiparous and multiparous cows. Error bars indicate standard error $\mathrm{ECM}=$ energy-corrected milk; $\mathrm{Cl}$ = calving interval; $\mathrm{EXT}=$ extended lactation.

For multiparous cows, a reason why a 16-month lactation appears less advantageous than for the primiparous cows might be that there are more days with low milk yield at the end of the lactation. However, on the lifetime scale, the multiparous cows could benefit from longer lactation by increasing their efficiency (Gaillard et al., 2016b). The higher rate of proliferation of mammary gland epithelial cells in primiparous cows as compared with multiparous cows (Miller et al., 2006) might partly explain the positive carryover of an EXT on primiparous cows' following lactations (milk production) and lifetime.

\section{Conclusion and perspectives on lifetime efficiency}

GARUNS model was used to predict productive and reproductive performances of cows managed for EXT. Modelling showed that the optimal lifetime scenario for production cows would be an EXT of 16 months at first parity cows, followed by 10 -month lactations for later parities. Further work should include health incidents to the prediction model to have predictions that are more accurate on the lifetime efficiency. The productive and reproductive performances predicted should then be compared with real data for cows managed for the optimum lifetime scenario defined by the model.

\section{Effects at herd and farm levels}

Deliberately delaying the time of first insemination for all or selected cows initiates a cascade of system effects at herd and farm levels. For the dairy herd, EXT can be expected to lead to fewer diseases per cow-year (365 feeding days) because the majority of diseases occur around the time of calving (Ingvartsen et al., 2003). Similarly, EXT leads to fewer calvings, fewer replacement heifers and fewer dry days per cow-year if dry period length is maintained, but replacement rate per lactation can be maintained despite more time per lactation for accidents etc. to happen (Lehmann et al., 2014; 2019). Together, this leads to lower total live-weight gain from males and females per cow-year and therefore a reduced production of beef.

Longer $\mathrm{Cls}$ also cause the cow herd on average to be more days in milk (longer time from latest calving), and to have a lower proportion of dry days per cow-year. This will increase the average feed intake capacity per unit of milk yield and hence allow for feeding the herd a low energy-rich diet on average. The combined reduction in replacement heifers and reduced need for an energy-rich diet during lactation will reduce and change the composition of total herd feed intake. In systems with on-farm forage production, this reduces the need for on-farm feed growing area and might change the crop rotation and the required composition of crops. Thus, an EXT strategy can have a profound effect on herd production of milk and meat, herd composition, herd feed intake and farm feed-growing area.

However, the magnitude of the cascade of effects described in the previous paragraphs depends on (1) the proportion of cows selected for EXT, (2) the parity of the selected cows and (3) the extent to which these cows have their EXT. These effects are in addition to the direct effect of EXT on milk yield per feeding day as well as possible interactions between EXT, health and fertility. Recently, a few studies have investigated different EXT (Table 4) and their consequences for herd milk production, profitability and GHG emissions per kilogram of milk.

Under pastoral conditions, Browne et al. (2015) compared 18- with 12-month $\mathrm{Cls}$ and showed an increased milk production per cow per year, an improved profitability and a reduced GHG emission per kilogram of milk. Kok et al. (2018) showed 
Sehested, Gaillard, Lehmann, Maciel, Vestergaard, Weisbjerg, Mogensen, Larsen, Poulsen and Kristensen

Table 4 Milk production, operating profit and GHG emission for different strategies for EXT (CI) in dairy cows at herd level

\begin{tabular}{|c|c|c|c|c|}
\hline Unit, reference and scenario & Calving interval & Milk yield & Operating profit & GHG \\
\hline Unit & Months & $\mathrm{kg} \mathrm{ECM/cow}$ & $€ /$ cow & $\mathrm{g} \mathrm{CO}_{2}$-eq./kg ECM \\
\hline \multicolumn{5}{|l|}{ Browne et al. (2015) ${ }^{1}$} \\
\hline $20 \%$ of DMI from conc & 12 & 6303 & 340 & 765 \\
\hline $20 \%$ of DMI from conc & 18 & 6697 & 371 & 691 \\
\hline $35 \%$ of DMI from conc & 12 & 7013 & 346 & 710 \\
\hline $35 \%$ of DMI from conc & 18 & 7447 & 363 & 642 \\
\hline \multicolumn{5}{|l|}{ Vellinga et al. $(2018)^{2}$} \\
\hline Baseline & 12 & 8458 & & 1069 \\
\hline All cows 14 months & 14 & 8458 & & 1065 \\
\hline All cows 15 months & 15 & 8458 & & 1067 \\
\hline \multicolumn{5}{|l|}{ Lehmann et al. (2019) } \\
\hline Baseline & 13 & 11054 & 2089 & 984 \\
\hline All cows 15 months & 15 & 10869 & 2086 & 979 \\
\hline All cows 17 months & 17 & 10633 & 2042 & 984 \\
\hline Primiparous 15 months & 15 & 11039 & 2099 & 982 \\
\hline Primiparous 17 months & 17 & 11014 & 2104 & 981 \\
\hline Multiparous 15 months & 15 & 10864 & 2071 & 983 \\
\hline Multiparous 17 months & 17 & 10603 & 2022 & 987 \\
\hline \multicolumn{5}{|l|}{ Kok et al. $(2018)^{3}$} \\
\hline Baseline, FC & 13 & 8776 & 1740 & 939 \\
\hline All cows 15 months , FC & 15 & 8439 & 1680 & 939 \\
\hline All cows 17 months , FC & 17 & 8161 & 1630 & 938 \\
\hline Primiparous 15 months , FC & 15 & 8717 & 1740 & 934 \\
\hline Primiparous 17 months , FC & 17 & 8598 & 1710 & 937 \\
\hline Baseline, VC & 13 & 8796 & 1740 & 939 \\
\hline All cows 15 months, VC & 15 & 8439 & 1670 & 949 \\
\hline All cows 17 months , VC & 17 & 8181 & 1620 & 955 \\
\hline Primiparous 15 months , VC & 15 & 8697 & 1720 & 941 \\
\hline Primiparous 17 months , VC & 17 & 8598 & 1700 & 943 \\
\hline
\end{tabular}

the opposite results under confinement conditions, whereas the results of Lehmann et al. (2019) differed depending on which groups of cows were submitted to EXT, and they argued that their estimated GHG emissions would all increase if emissions from displaced meat production were included based on beef breed cattle. Browne et al. (2015), Kok et al. (2018) and Lehmann et al. (2019) include a change in replacement rate with a concomitant change in cow longevity, either as a default or because of other model assumptions. The increase in lifespan is a major reason for the reduction in GHG emissions per unit milk, because fewer replacement heifers are reared and these heifers are costly in terms of emissions. This is a major part of the explanation for the dynamics and derived consequences of implementing an EXT strategy. An EXT strategy will inevitably reduce meat production as fewer calves are born, but the combined use of sexed dairy semen and beef semen could partially compensate for this if the sector requires an unchanged amount of beef. The use of sexed dairy semen and beef semen could also offset the genetic lag caused by an EXT strategy (Clasen et al., 2018).

Table 4 indicates that it is economically more advantageous to manage primiparous cows for EXT, as compared with managing all cows for EXT. However, to our knowledge, no empirical study has so far investigated the effect of managing the most persistent cows for EXT while managing the remaining herd for STD lactations. Through modelling both Lehmann et al. (2019) and Kok et al. (2018) found than an improved lactation persistency substantially improves lactation yield and the economic effect of EXT, and that a selection of the most suitable cows for EXT could lead to this effect. Suitable cows could be cows with a high milk production in early lactation relative to other cows in the herd (Lehmann et al., 2017), but more work is needed to determine which cows are more suitable than others. However, the economic consequences estimated by Browne et al. (2015) under pastoral, seasonal conditions as well as by 
Kok et al. (2018) and Lehmann et al. (2019) under confinement conditions highly depend on the costs included. Thus, Lehmann et al. (2019) showed that accounting for a potential change in labour costs would have a major impact on the estimated economic effect of implementing an EXT.

Furthermore, Lehmann et al. (2019) showed that the potential reduction in the area required for feed production leads to a positive economic effect, either through an increased number of cows in the herd or growing a cash crop, which far exceeded the estimated direct economic effect of EXT.

\section{Conclusion and perspectives at herd and farm levels}

Deliberately delaying the time of first insemination sets off a cascade of effects at cow, herd and farm levels. Economically it seems most advantageous to manage primiparous cows for EXT, as compared with managing all cows for EXT. Selecting the most suitable cows for EXT could support the positive economic effect of EXT. The EXT strategy has potential to decrease estimated GHG emissions, but GHG emissions increase if displaced meat production is included based on beef breed cattle. There is a scope for optimisation of EXT through a selection of the most suitable cows as well as finding ways of realising the potential reduction in land use for feed growing, which could lead to an economic benefit for the farmer.

\section{Conclusions}

Dairy cows managed for EXT can maintain or even slightly increase daily milk yield through a $\mathrm{Cl}$ and achieve a higher lifetime milk production while delivering milk with unchanged or improved quality properties. Delaying insemination enhances mounting behaviour and allows insemination after the cow's EB has become positive. However, in most cases EXT has no effect or a non-significant positive effect on reproduction. The EXT strategy sets off a cascade of effects at herd and farm levels. Thus, the EXT strategy leads to fewer calvings and thereby expected fewer diseases, fewer replacement heifers and fewer dry days per cow per year. The optimal lifetime scenario for milk production was modelled to be an EXT of 16 months for first parity cows followed by an EXT of 10 months for later lactations. Modelling studies of herd dynamic indicate a positive effect of EXT on lifetime efficiency (milk per dry matter intake (DMI)), mainly originating from benefits of EXT on daily milk yield in primiparous cows and the reduced number of replacement heifers. Consequently, EXT also leads to reduced total meat production at herd level. For the farmer, EXT can give the same economic return as a traditional lactation period. At farm level, EXT will contribute to a reduction in the environmental impact of dairy production, mainly because of a reduced herd feed use through fewer young stock and dry cows. A wider dissemination of the EXT concept will be supported by methods to predict which cows may be most suitable for EXT, and clarification of how milking frequency and feeding strategy through the lactation can be organised to support milk yield and an appropriate body condition at the next calving.

\section{Acknowledgements}

The authors wish to thank the Danish Council for Strategic Research, the Programme Commission on Health, Food and Welfare and Aarhus University for the financial support for the REPROLAC project (Grant no 11-116247). The authors also would like to thank the farmers and technicians involved in the REPROLAC experiments for their highly committed efforts.

\section{(1) J. Sehested, https://orcid.org/0000-0001-6977-6972}

\section{Declaration of interest}

The authors declare that there is no conflict of interest in this review.

\section{Ethics statement}

No original data are presented in this review, and no ethics approval was sought or required.

\section{Software and data repository resources}

No software or data were deposited anywhere as part of this review.

\section{References}

Auldist MJ, Coats S, Sutherland BJ, Mayes JJ, McDowell GH and Rogers GL 1996. Effects of somatic cell count and stage of lactation on raw milk composition and the yield and quality of Cheddar cheese. The Journal of Dairy Research 63, 269-280.

Auldist MJ, Grainger C, Houlihan AV, Mayes JJ and Williams RPW 2010. Composition, coagulation properties, and cheesemaking potential of milk from cows undergoing extended lactations in a pasture-based dairying system. Journal of Dairy Science 93, 1401-1411.

Auldist MJ, O'Brien G, Cole D, Macmillan KL and Grainger C 2007. Effects of varying lactation length on milk production capacity of cows in pasture-based dairying systems. Journal of Dairy Science 90, 3234-3241.

Bach A, Valls N, Solans A and Torrent T 2008. Associations between non dietary factors and dairy herd performance. Journal of Dairy Science 91, 3259-3267.

Bar-Anan R and Genizi A 1981. The effects of lactation, pregnancy and calendar month on milk records. Animal Science 33, 280-290.

Bertilsson J, Berglund B, Ratnayake G, Svennersten-Sjaunja K and Wiktorsson H 1997. Optimising lactation cycles for the high yielding dairy cow. A European perspective. Livestock Production Science 50, 5-13.

Bossen D and Weisbjerg MR 2009. Allocation of feed based on individual dairy cow live weight changes II: effect on milk production. Livestock Science 126, 273-285.

Brotherstone S, Thompson R and White IMS 2004. Effects of pregnancy on daily milk yield of Holstein-Friesian dairy cattle. Livestock Production Science 87, 265-269.

Browne NA, Behrendt R, Kingwell RS and Eckard RJ 2015. Does producing more product over a lifetime reduce greenhouse gas emissions and increase profitability in dairy and wool enterprises? Animal Production Science 55, 49-55.

Butler WR 2000. Nutritional interactions with reproductive performance in dairy cattle. Animal Reproduction Science 60, 449-457.

Christiansen HC, Danfær A and Sehested J 2005. Koens reaktion på forskelle planlagt kælvningsinterval og energiforsyning. In Økologisk mælkeproduktion: Fodring og management ved høj selvforsyning. FØJO-rapport nr. 20 (ed. 
Sehested, Gaillard, Lehmann, Maciel, Vestergaard, Weisbjerg, Mogensen, Larsen, Poulsen and Kristensen

T Kristensen), pp. 13-26. Forskningscenter for Økologisk Jordbrug (FØJO), Tjele, Denmark.

Clasen JB, Lehmann JO, Thomasen JR, Østergaard S and Kargo M 2018. Combining extended lactation with sexed semen in a dairy cattle herd: effect on genetic and total economic return. Livestock Science 223, 176-183.

Gaillard C 2016. Extended lactation and feeding strategies in dairy cows. PhD thesis, Department of Animal Science, Aarhus University, Denmark.

Gaillard C, Barbu H, Callesen H, Sørensen MT, Sehested J and Vestergaard M. 2016a. Milk yield and estrus behavior during eight consecutive estruses of Holstein cows grouped according to live weight change in early lactation. Journal of Dairy Science 99, 3134-3143.

Gaillard C, Martin O, Blavy P, Friggens N, Sehested J and Phuong H 2016b. Prediction of the reproductive lifetime performance of Holstein cows managed for different durations, using a model of lifetime nutrient partitioning. Journal of Dairy Science 99, 9126-9135.

Gaillard C, Vestergaard M, Weisbjerg MR and Sehested J 2016c. Effects of live weight adjusted feeding strategy on plasma indicators of energy balance in Holstein cows managed for extended lactation. Animal 10, 633-642.

Garnsworthy PC, Masson LL, Lock AL and Mottram TT 2006. Variation of milk citrate with stage of lactation and de novo fatty acid synthesis in dairy cows. Journal of Dairy Science 89, 1604-1612.

Grainger C, Auldist MJ, O'Brien G, Macmillan KL and Culley C 2009. Effect of type of diet and energy intake on milk production of Holstein-Friesian cows with extended lactations. Journal of Dairy Science 92, 1479-1492.

Ingvartsen KL, Dewhurst RJ and Friggens N 2003. On the relationship between lactational performance and health: is it yield or metabolic imbalance that cause production disease in dairy cattle? A position paper. Livestock Production Science 83, 277-308.

Kay JK, Aspin PW, Phyn CVC, Roche JR and Kolver ES 2007. Production and physiological indicators to select cows suitable for extended lactations. Proceedings of the $67^{\text {th }}$ Conference of the New Zealand Society of Animal Production, 20-22 June 2007, Wanaka, New Zealand, pp. 315-319.

Kok A, Lehmann JO, Kemp B, Hogeveen H, van Middelaar CE, de Boer IJM and van Knegsel ATM 2018. Production, cash flows and greenhouse gas emissions of simulated dairy herds with extended lactations. Animal 13, 1074-1083.

Kolver ES, Roche JR, Burke CR, Kay JK and Aspin PW 2007. Extending lactation in pasture-based dairy cows: I. Genotype and diet effect on milk and reproduction. Journal of Dairy Science 90, 5518-5530.

Lagrange V, Whitsett D and Burris C 2015. Global market for dairy proteins. Journal of Food Science 80, A16-A22.

Larsson B and Berglund B 2000. Reproductive performance in cows with extended calving interval. Reproduction in Domestic Animals 35, 277-280.

Lehmann J0 2016. Extended lactation in Danish dairy production. PhD thesis, Department of Agroecology, Aarhus University, Denmark.

Lehmann JO, Fadel JG, Mogensen L, Kristensen T, Gaillard C and Kebreab E 2016. Effect of calving interval and parity on milk yield per feeding day in Danish commercial dairy herds. Journal of Dairy Science 99, 621-633.

Lehmann J0, Mogensen L and Kristensen T 2014. Extended lactations may improve cow health, productivity and reduce greenhouse gas emissions from organic dairy production. Organic Agriculture 4, 295-299.

Lehmann JO, Mogensen L and Kristensen T 2017. Early lactation production health, and welfare characteristics of cows selected for extended lactation. Journal of Dairy Science 100, 1487-1501.

Lehmann JO, Mogensen L and Kristensen T 2019. Extended lactations in dairy production: economic, productivity and climatic impact at herd, farm and sector level. Livestock Science 220, 100-110.

Maciel GM 2016. Impact of some farm-related practices and first processing steps on milk quality for cheese production, PhD thesis, Department of Food Science, Aarhus University, Denmark.

Maciel GM, Mogensen L, Lehmann JO, Kidmose U, Kristensen T, Larsen LB and Poulsen NA 2017. Impaired milk quality and cheese making properties is not a concern for managing cows for 15 or 18 months calving intervals. International Dairy Journal 70, 2-11.

Maciel GM, Poulsen NA, Larsen MK, Kidmose U, Gaillard C, Sehested J and Larsen LB 2016. Good sensory quality and cheesemaking properties in milk from Holstein cows managed for an 18-month calving interval. Journal of Dairy Science 99, 8524-8536.

Markusfeld 0 and Ezra E 1993. Body measurements, metritis, and postpartum performance of first lactation cows. Journal of Dairy Science 76 , 3771-3777.

Martin 0 and Sauvant D 2010. A teleonomic model describing performance (body, milk and intake) during growth and over repeated reproductive cycles throughout the lifespan of dairy cattle. 1. Trajectories of life function priorities and genetic scaling. Animal 4, 2030-2047.

Miller N, Delbecchi L, Petitclerc D, Wagner GF, Talbot BG and Lacasse P 2006. Effect of stage of lactation and parity on mammary gland cell renewal. Journal of Dairy Science 89, 4669-4677.

Murney R, Stelwagen K, Wheeler TT, Margerison JK and Singh K 2015. The effects of milking frequency in early lactation on milk yield, mammary cell turnover, and secretory activity in grazing dairy cows. Journal of Dairy Science 98 305-311.

Osterman S and Bertilsson J 2003. Extended calving interval in combination with milking two or three times per day: effects on milk production and milk composition. Livestock Production Science 82, 139-149.

Phuong HN, Blavy P, Martin O, Schmidely P and Friggens NC 2015. Modelling impacts of performance on the probability of reproducing, and thereby on productive lifespan, allow prediction of lifetime efficiency in dairy cows. Animal 10, 106-116.

Pryce JE, Royal MD, Garnsworthy PC and Mao IL 2004. Fertility in the high-producing dairy cow. Livestock Production Science 86, 125-135.

Ratnayake D, Berglund B, Bertilsson J, Forsberg M and Gustafsson H 1998. Fertility in dairy cows managed for calving intervals of 12,15 or 18 months. Acta Veterinaria Scandinavica 39, 215-228.

Rehn H, Berglund B, Emanuelson U, Tengroth G and Philipsson J 2000. Milk production in Swedish dairy cows managed for calving intervals of 12 and 15 months. Acta Agriculturae Scandinavica, Section A - Animal Science 50 263-271.

Sawa A and Bogucki M 2009. Effect of extended lactations on cow milk and reproductive performance. Archiv Fur Tierzucht-Archives of Animal Breeding $52,219-229$.

Schindler H, Eger S, Davidson M, Ochowski D, Schermerhorn EC and Foote RH 1991. Factors affecting response of groups of dairy cows managed for different calving conception intervals. Theriogenology 36, 495-503.

Sorensen A, Muir DD and Knight $\mathrm{CH}$ 2008. Extended lactation in dairy cows: effects of milking frequency, calving season and nutrition on lactation persistency and milk quality. Journal of Dairy Research 75, 90-97.

Stockdale CR 2006. Influence of milking frequency on the productivity of dairy cows. Australian Journal of Experimental Agriculture 46, 965-974.

van Amburgh ME, Galton DM, Bauman DE and Everett RW 1997. Management and economics of extended calving intervals with use of bovine somatotropin. Livestock Production Science 50, 15-28.

Veerkamp RF, Hill WG, Stott AW, Brotherstone S and Simm G 1995. Selection for longevity and yield in dairy cows using transmitting abilities for type and yield. Animal Science 61, 189-197.

Vellinga TV and de Vries M 2018. Effectiveness of climate change mitigation options considering the amount of meat produced in dairy systems. Agricultural Systems 162, 136-144.

Wall E, Coffey MP and Pollott GE 2012. The effect of lactation length on greenhouse gas emissions from the national dairy herd. Animal 6, 1857-1867.

Wathes DC, Cheng Z, Bourne N, Taylor VJ, Coffey MP and Brotherstone S 2007. Differences between primiparous and multiparous dairy cows in the interrelationships between metabolic traits, milk yield and body condition score in the periparturient period. Domestic Animal Endocrinology 33, 203-225. 